\title{
Environmental Impacts-Coastal Ecosystems, Birds and Forests
}

\author{
Pekka Niemelä, Harri Tolvanen, Mia Rönkä, Seppo Kellomäki, \\ Joachim Krug, Guy Schurgers, Esa Lehikoinen, and Risto Kalliola
}

\begin{abstract}
This chapter describes observed historical and projected future impacts of climate change on the coastal and terrestrial ecosystems of the Baltic Sea basin. Because terrestrial and aquatic ecosystems interact, this chapter gives particular emphasis to the coastal zone as a contact area for terrestrial, marine and atmospheric processes. Archipelagos and post-glacial land uplift are particular features of the Baltic Sea basin and so receive special consideration. This chapter comprises three main sections. The first describes coastal zone and archipelago ecosystems in the Baltic Sea region and evaluates the potential impacts of climate change. The second examines a case study for the effect of current and future climate change on coastal bird populations and communities. The third evaluates the effects of current and future climate change on forests and natural plant communities in the Baltic Sea basin and the ways in which terrestrial ecosystems may interact with aquatic ecosystems. Climate-related changes in carbon storage are also discussed.
\end{abstract}

\section{$16.1 \quad$ Introduction}

This chapter describes observed historical and projected future impacts of climate change on the coastal and terrestrial ecosystems of the Baltic Sea basin. This region contains

P. Niemelä $(\bowtie) \cdot$ M. Rönkä · E. Lehikoinen

Department of Biology, University of Turku, Turku, Finland e-mail: pekka.niemela@utu.fi

H. Tolvanen · R. Kalliola

Department of Geography and Geology, University of Turku, Turku, Finland

\section{S. Kellomäki}

Faculty of Science and Forestry, University of Eastern Finland, Joensuu, Finland

\section{J. Krug}

Thünen-Institute, Institute for World Forestry, Leuschner Str. 91, 21031 Hamburg, Germany

G. Schurgers

Department of Earth and Ecosystem Science, Lund University, Lund, Sweden many types of ecosystem, such as boreal and hemiboreal forests, peatlands, arable and other human modified lands, freshwater and riparian ecosystems and diverse coastal environments. Terrestrial and aquatic ecosystems interact and so this chapter focuses particularly on the coastal zone as a contact area for terrestrial, marine and atmospheric processes. Archipelagos are a particular feature of the Baltic Sea basin and so receive special emphasis. Thus, the focus of this chapter is on ecosystems that received little or no attention in previous assessment of climate change in the Baltic Sea basin (BACC Author Team 2008).

A special feature of the Baltic Sea region is land uplift. Currently, the rate of land uplift in the Baltic Sea region is -1 to $9 \mathrm{~mm}$ year $^{-1}$ (Leppäranta and Myrberg 2009; see also Chap. 9, Sect. 9.2). Although marine regression has been the prevailing process on the coasts, periods of marine transgression (shoreline advance) have also occurred (Björck 1995). Thus, the transitional zone between the terrestrial and marine realms is considered particularly changeable, which highlights the necessity to address the aquatic dynamics of 
the Baltic Sea within the contexts of sea-level rise (Chaps. 9 and 14) and drainage basin processes. It is important to emphasise the combined effect of climate change impacts and post-glacial land uplift on coastal ecosystems, especially in the northern parts of the Baltic Sea basin.

The sensitivity to human-induced change is particularly evident in terms of the water volume of the Baltic Sea. Water volume divided by the number of inhabitants in the drainage basin equates to about $250,000 \mathrm{~m}^{3}$ per capita. This is only $0.13 \%$ of the value calculated for the World Ocean and the total world population $\left(186,000,000 \mathrm{~m}^{3}\right.$ per capita). A strong human influence in the Baltic Sea catchment area also results from the high population pressure (80-90 million inhabitants) and because around $20 \%$ of the overall land area is arable land concentrated towards the south (Sweitzer et al. 1996). Thus, the marine ecosystem is under considerable pressure from the land: both in abiotic terms (such as temperature change and pollutant inputs) and biotic terms (such as from invasive species).

This chapter focuses on ecosystems and processes that are unique and vulnerable to environmental change, including climate change. Section 16.2 describes coastal zone and archipelago ecosystems in the Baltic Sea region and evaluates the potential impacts of climate change on the interaction between aquatic and terrestrial ecosystems. Section 16.3 examines the effect of current and future climate change on coastal birds and bird communities. Section 16.4 evaluates the effects of current and future climate change on forests, natural vegetation and carbon storage in the Baltic Sea basin.

\section{2 \\ The Coastal Zone and Shorelines}

\subsubsection{Heterogeneity Implies Regionally Different Effects}

Coastal areas play key roles in the interaction between terrestrial and aquatic systems. The coastal zone comprises the marine areas under terrestrial influence, as well as the terrestrial environment under marine influence (Tolvanen and Kalliola 2008). The ecosystems of the coastal areas are unique in combining both realms. Human occupancy and its impacts are exceptionally diverse in the often densely populated coastal areas.

The total shoreline of the Baltic Sea measures 76,000 km (HELCOM 2012). The distribution of shorelines of different complexity (Bartley et al. 2001) shows remarkable variety, from soft-formed depositional shores to the complex fractal shorelines of the bedrock-dominated archipelagos. Shore density (length of shoreline per unit area) provides a good indicator of shoreline complexity, which is highly variable in the Baltic Sea region (Fig. 16.1).

Shore density is not the only parameter with significant regional variation on the Baltic Sea coasts: the amount of nearshore areas also varies, both on the littoral and terrestrial sides (Fig. 16.1). The importance of edge effects becomes apparent when high shore density areas are considered as ecosystem patches - the nearshore ecosystems prevail in high shore density areas compared to the less complex
Fig. 16.1 Shore density in three $100 \mathrm{~km}^{2}$ square cells on the Baltic Sea coast. The insets show detail concerning shore density and the nearshore zone as a buffer area extending $1 \mathrm{~km}$ from the shoreline. The nearshore zone covers $74 \%$ in area $A, 2 \%$ in $B$ and $19 \%$ in $C$. Computed from HELCOM (2012)
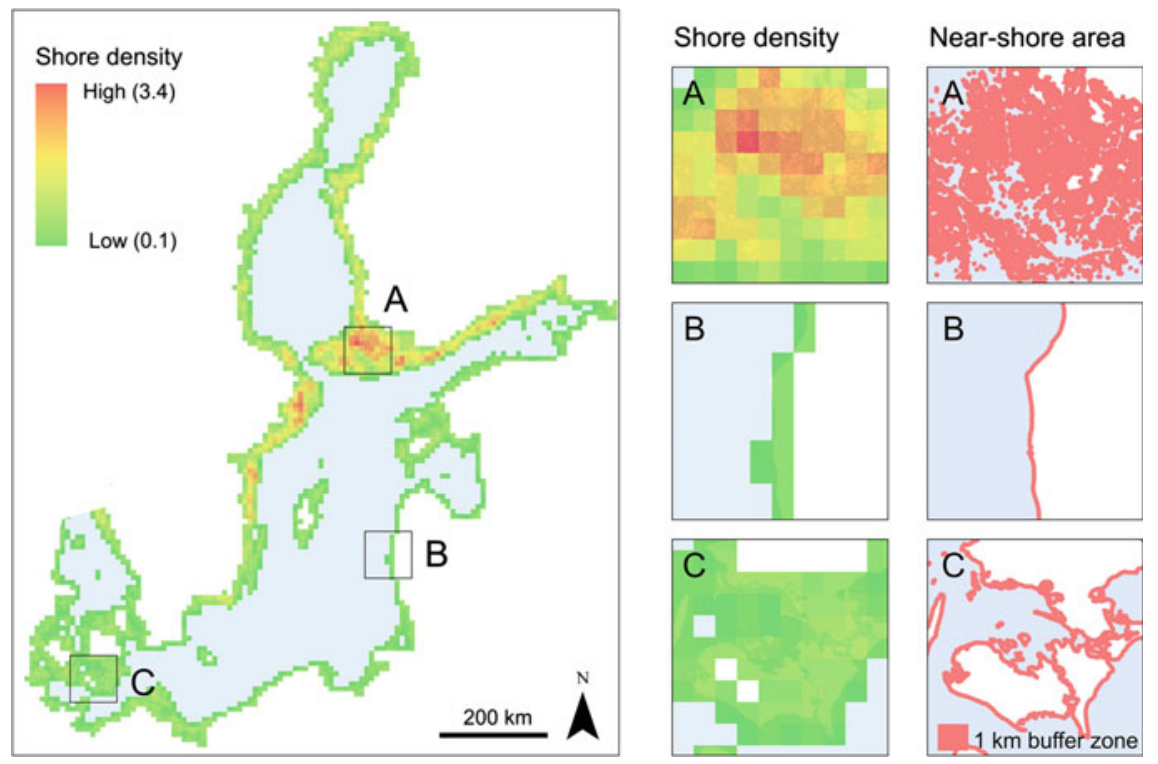
coastal settings in other areas. Biodiversity of plant and animal communities is generally highest on the edges of different habitats because edges share species from both habitats. In addition, areas with different land-water transitions may respond differently to anticipated change, for example climate-related sea-level rise.

In areas with a wide coastal zone, from the mainland to the outermost islets, the transition from the terrestrial to the marine environment is often gradual. A wide coastal area may show distinct inner, middle and outer zones, with characteristic physical dimensions and ecological responses (e.g. Häyrén 1900; Granö 1981; Jaatinen 1984; Granö and Roto 1989 b). This transition may be particularly sensitive to environmental change in the interface between the terrestrial and marine systems.

Post-glacial land uplift progresses at different rates in different Baltic Sea coastal areas. While uplift is almost $1 \mathrm{~cm}$ year $^{-1}$ in the Bothnian Bay, the southernmost coasts of the Baltic Sea undergo slight submergence (Eronen 2005; Myrberg et al. 2006; see also Chap. 9). Figure 16.2 shows the proportion of coastal areas in each uplift category. These differences are crucially important in relation to projections of global sea-level rise (see Chap. 14). It is noteworthy that land uplift is also a process that creates particular coastal environments, such as closing bays (flad to glo-lake continuum (see Tolvanen et al. 2004)), and these processes work at different rates in different parts of the Baltic Sea.

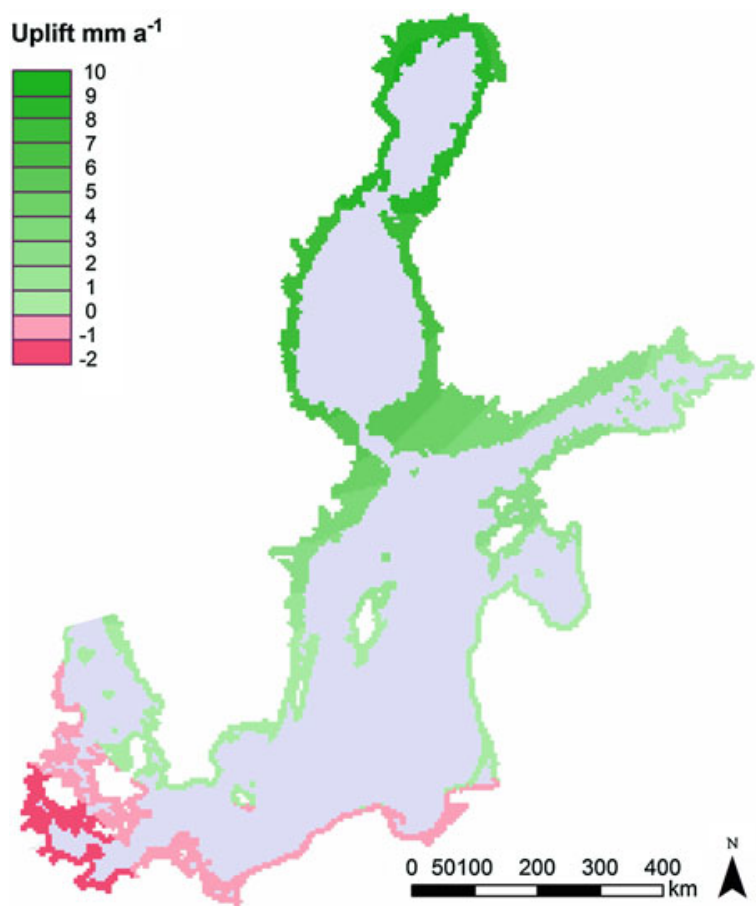

Fig. 16.2 Rate of post-glacial land uplift in $25 \mathrm{~km}^{2}$ square cells along the coasts of the Baltic Sea (uplift rates from Voipio and Leinonen 1984)
There is a wide variety of shore types on the Baltic Sea coasts: chalk cliffs, barrier islands with coastal lagoons, sandy beaches, flat clay shores, rocky shores and esker shores (see also Chap. 20). All these environments are subject to particular erosional and depositional processes, which are mediated by different shore-forming forces such as wave energy. These drivers, in turn, vary in response to changing weather conditions making them sensitive to climate change. Furthermore, the prevailing processes in the shore areas are also affected by the post-glacial land uplift of the Fennoscandian crust. There are several ways to classify coastal areas (e.g. Bird 2000; Fairbridge 2004; Finkl 2004) and the Baltic Sea coasts have been classified by several authors (Furman et al. 1998; Frisén et al. 2005; HELCOM 2012; see also Chap. 20). HELCOM (2012) presented six coastal types based on the structural appearance of the coast: - Archipelagos - the mainland shoreline does not face the open sea

- Bodden coasts with lagoons-low elevation coasts with dynamic sediment balances

- Cliffs - erosional shores of soft sedimentary rocks

- Fjords and rocky shores - hard rock environments with glacial erosion patterns

- Intended low coasts - low elevation coasts with marshes and skerries

- Open low coast - often sandy dynamic coasts.

Shore openness defines the shore's exposure to the open sea and so portrays the wave formation potential (Ekebom et al. 2003; Tolvanen and Suominen 2005; Murtojärvi et al. 2007). On coasts with low shore density, the shore openness is generally high, while on high shore density coasts, most of the shoreline is sheltered by surrounding islands.

Owing to its restricted connection to the World Ocean, the Baltic Sea is effectively non-tidal. There are, however, irregular water level fluctuations caused by changes in atmospheric pressure, precipitation, wind strength and standing wave oscillation (seiche) (Myrberg et al. 2006; Chap. 9). The combined effect of these factors may under some circumstances cause local sea-level fluctuations in large bays of up to $3.2 \mathrm{~m}$ in the northernmost part of the Bothnian Bay (Frisén et al. 2005). An increase in the magnitude and frequency of extreme weather events may increase the frequency of extreme water level events (i.e. surges) on the Baltic Sea coasts. During warmer than normal winters, storms can also cause local sea-level rise, which together with ice dams in rivers and seiche fluctuations may increase winter flooding of Baltic Sea shores.

The formation of sea ice influences Baltic Sea shores (see also Chap. 8). Ice usually forms first in shallow inland bays, extending gradually towards the open sea. Sea ice in contact with the shore can cause local erosion through tearing as well as deposition by ice push (e.g. Forbes and Taylor 1994). Annual sea ice dynamics vary from year to year depending 
Fig. 16.3 Land use within $1 \mathrm{~km}$ of the shoreline (excluding the Russian Federation) in $100 \mathrm{~km}^{2}$ square cells. Computed and generalised from the CORINE land use classification, EEA (2006)
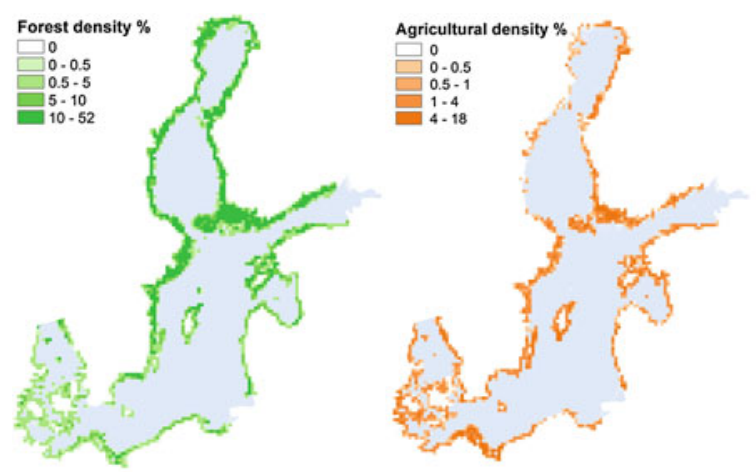

on changes in winter temperature, storms and water level fluctuations and sometimes also on the weight of snow on ice (Chap. 8). These variations influence shore geomorphology, ecosystems and human livelihoods. If winters become warmer, it is likely that significant changes will occur in the ice conditions of the Baltic Sea (Omstedt and Nyberg 1997). As a consequence, sea ice interaction with the shores of the Baltic Sea may decrease in importance, and open water conditions with wave energy-induced dynamism may become more important (see also Chap. 20).

Human influences of terrestrial origin are diverse and induce various pressures on the coastal and marine systems. Eutrophication is especially sensitive to changes in atmospheric and hydrological processes, with consequent alterations in nutrient input and biological processes (HELCOM 2009). Maritime activities and shore protection also cause physical stress, which is particularly relevant for shallow coasts and archipelagos (e.g. Eriksson et al. 2004).

Land use varies greatly within the Baltic Sea basin (see also Chaps. 21 and 25). The most notable contrast is between the agricultural south and the forested north
(Sweitzer et al. 1996). When only the immediate vicinity of the shoreline is considered, the north-south contrast is less striking (Fig. 16.3). The land-use patterns within $1 \mathrm{~km}$ of the shoreline reflect the high human occupancy of the coastal areas: urban areas are frequent, especially in the Scandinavian countries and Finland, where shoreline development and private land ownership on shores has been allowed to a greater degree than in the Baltic States and Poland.

\subsubsection{Impacts of Climate Change on Coastal Areas}

The Baltic Sea coasts show a large variety of environments on which climate change may have strong effects (Kont et al. 1997, 2003; Neumann and Friedland 2011; Störmer 2011) (Table 16.1). Some of the ecosystem responses are particular to the relatively simple-structured brackish water ecosystems of the Baltic Sea. Therefore, a comprehensive view of the regional geography and distribution of the different habitats within the drainage area is important when assessing the pattern of future change.

Table 16.1 Summary of potential climate change impacts on coastal areas of the Baltic Sea

\begin{tabular}{|c|c|c|c|}
\hline Change & \multicolumn{2}{|l|}{ Consequences } & Response \\
\hline \multirow{3}{*}{$\begin{array}{l}\text { Atmospheric warming } \\
\text { (see Chap. 4) }\end{array}$} & \multicolumn{2}{|c|}{ Warmer terrestrial ecosystems (e.g. Hickling et al. 2006) } & \multirow{2}{*}{$\begin{array}{l}\text { Northward migration of terrestrial and } \\
\text { aquatic species, longer productive season } \\
\text { (e.g. Chapin et al. 2007; MacKenzie et al. } \\
\text { 2007; Burrows et al. 2011) }\end{array}$} \\
\hline & \multicolumn{2}{|c|}{ Warmer coastal sea water (e.g. Omstedt et al. 2004) } & \\
\hline & \multicolumn{2}{|c|}{$\begin{array}{l}\text { Decreased extent, thickness and duration of annual sea ice in coastal } \\
\text { waters (e.g. Vihma and Haapala 2009) }\end{array}$} & $\begin{array}{l}\text { Changes in marine ecosystems and physical } \\
\text { features of the sea (see Chap. 19) }\end{array}$ \\
\hline \multirow{2}{*}{$\begin{array}{l}\text { Potential increase in } \\
\text { precipitation (e.g. } \\
\text { Zolina et al. 2010) }\end{array}$} & $\begin{array}{l}\text { Potentially increased terrestrial run- } \\
\text { off }\end{array}$ & $\begin{array}{l}\text { Decreased coastal water } \\
\text { salinity }\end{array}$ & $\begin{array}{l}\text { Changes in species composition and } \\
\text { ecosystem function (see Chap. 19) }\end{array}$ \\
\hline & $\begin{array}{l}\text { Increased river-borne sediment, } \\
\text { dissolved organic material and } \\
\text { nutrient loads }\end{array}$ & $\begin{array}{l}\text { Changes in water chemistry, } \\
\text { decreased coastal water } \\
\text { transparency }\end{array}$ & $\begin{array}{l}\text { Eutrophication; shallower distribution of } \\
\text { aquatic plants, decreased and fragmented } \\
\text { benthic and littoral habitats (see Chap. 19) }\end{array}$ \\
\hline \multirow{2}{*}{$\begin{array}{l}\text { Acceleration in global } \\
\text { sea-level rise (e.g. } \\
\text { Omstedt et al. 2004; } \\
\text { Donner et al. 2012) }\end{array}$} & $\begin{array}{l}\text { Decreased or reversed relative land } \\
\text { uplift (e.g. Hammarklint 2009) }\end{array}$ & $\begin{array}{l}\text { Shoreline retreat slowed or } \\
\text { reversed (e.g. Johansson et al. } \\
2004 \text { ) }\end{array}$ & \multirow[t]{2}{*}{$\begin{array}{l}\text { Changes in littoral ecosystems (see Chap. 19), } \\
\text { need for coastal defence (see Chap. 20) }\end{array}$} \\
\hline & $\begin{array}{l}\text { Increased land submergence (e.g. } \\
\text { Richter et al. 2012) }\end{array}$ & $\begin{array}{l}\text { Accelerated shoreline advance } \\
\text { (e.g. Johansson et al. 2004) }\end{array}$ & \\
\hline
\end{tabular}




\subsubsection{The SW-Finnish Archipelago as an Example of a Particularly Sensitive Coastal Environment}

The presence of extensive archipelago coasts is a particular feature of the Baltic Sea. In these areas, the interaction between the terrestrial and marine realms can be particularly complex. The Fennoscandian ice sheet of the Pleistocene glaciation retreated from SW Finland about 10,500 cal. year BP (Frisén et al. 2005; see also Chap. 2). The region is now characterised by a fragmented bedrock surface of the Fennoscandian Shield, with local relative elevations up to $100 \mathrm{~m}$. As the bedrock base surface is slightly tilted to the west and is partially submerged, the result is an archipelago coast with an east-west transition from a land-dominated inner archipelago to a water-dominated skerry landscape at the edge of the open sea (Fig. 16.4). The width of this transition zone is up to $150 \mathrm{~km}$ of continuous archipelago area. On a 1:10,000 map, the SW-Finnish archipelago alone, excluding the Åland Islands, contains more than 56,000 islands. About 8500 of these are larger than 1 ha (Stock et al. 2010). Water depth is generally less than $20 \mathrm{~m}$, but exceeds $100 \mathrm{~m}$ in areas of bedrock faults. The archipelago has about $15,000 \mathrm{~km}$ of shoreline within an area of roughly $10,000 \mathrm{~km}^{2}$, giving an average shore density of 1.5 (Granö et al. 1999), ranging locally from 0 to 12.5 (Tolvanen and Suominen 2004).

The bedrock base is partially covered by till or fluvioglacial deposits and occasionally by marine sediments since the area was initially submerged after the deglaciation. Shore processes have affected these sediments, leaving the highest bedrock areas bare and accumulating sediments on the slopes and in nearby sea basins (Granö and Roto 1986). The current glacio-isostatic land uplift rate of $3-5 \mathrm{~mm}_{\text {year }}{ }^{-1}$ on the SWFinnish coast (Suutarinen 1983; Kakkuri 1987; Vestøl 2006) has created a mosaic of bare bedrock and sedimentary surfaces along the shores, which are subject to primary succession.

The exceptionally high shore density is a result of abundant small-scale geomorphological details and gives rise to some special shore forms characteristic of the land uplift environment and habitats (Schwartz et al. 1989; Munsterhjelm 1997; Tolvanen et al. 2004). These land uplift habitats harbour specialised fauna and flora important for biodiversity (Vartiainen 1988). The physical conditions on the islands and shores are diverse and can differ notably between adjacent islands of similar size. The small-scale mosaic of islands and shallow water areas, with numerous small habitat patches, creates habitat edges and thus increases the biodiversity of the region (von Numers 1995; Boström et al. 2006). Shallow semi-enclosed bays often indicate intermediate characteristics between terrestrial and marine systems.

Salinity in the SW-Finnish archipelago ranges from 3.5 to 7.0 (Viitasalo et al. 1990). Annual ice cover can last for up to 100 days (Seinä and Peltola 1991), but ice duration is shortening (Haapala and Leppäranta 1997). Water temperature in the surface mixed layer reaches $20-25^{\circ} \mathrm{C}$ in August. December is the windiest month with an average wind speed of $8.3 \mathrm{~m} \mathrm{~s}^{-1}$, while May, June and July show the lowest average wind speed of $5.3 \mathrm{~m} \mathrm{~s}^{-1}$ (FMI 1991). The predominant wind directions during the ice-free season are southerly, south-westerly and westerly (Heino 1994).

Water currents in the SW-Finnish archipelago are typically slow $\left(<15 \mathrm{~cm} \mathrm{~s}^{-1}\right)$ (Virtaustutkimuksen neuvottelukunta 1979), but faster currents occur occasionally in narrow straits. Flow direction and intensity vary depending on atmospheric pressure and wind patterns. Islands and underwater thresholds create small local basins, in which freshwater run-off mixes with offshore water, resulting in a dynamic mosaic of sea water of different origins and properties.

There are four-dimensional geographical patterns and seasonal dynamics in the water properties of the SW-Finnish archipelago. Importantly, many of these spatial or temporal patterns differ for the different sea water properties (turbidity, salinity, acidity and temperature) (Suominen et al.2010a). For example, salinity shows considerable spatial, seasonal and interannual variability (Suominen et al. 2010b), challenging the physiological limits of many species living at the edge of their salinity tolerance. Eutrophication resulting from terrestrial run-off is a common environmental problem in the region (Lundberg et al. 2005; HELCOM 2009).

Penetration of solar radiation into the surface waters is strongly influenced by many optical constituents of terrestrial origin, such as suspended sediment and dissolved organic material, as well as by in situ phytoplankton populations (Kirk 2011). The inner archipelago is relatively turbid throughout the year due to suspended sediment from rivers and shallow clay bottoms. In the middle and outer
Fig. 16.4 The SW-Finnish archipelago, including the Åland Islands towards the west. Shoreline data from HELCOM (2012)
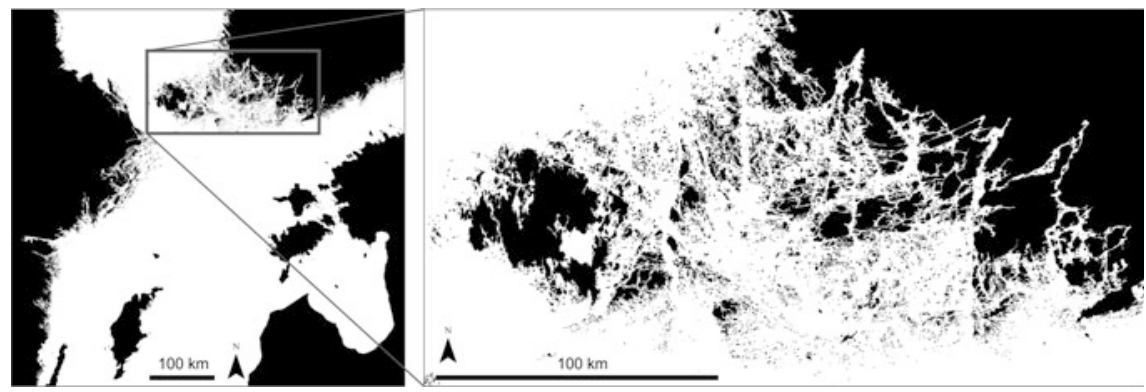
Fig. 16.5 Sea surface openness as average fetch in $1 \mathrm{~km}^{2}$ square cells on the SW-Finnish archipelago coast, computed after Tolvanen and Suominen (2005)

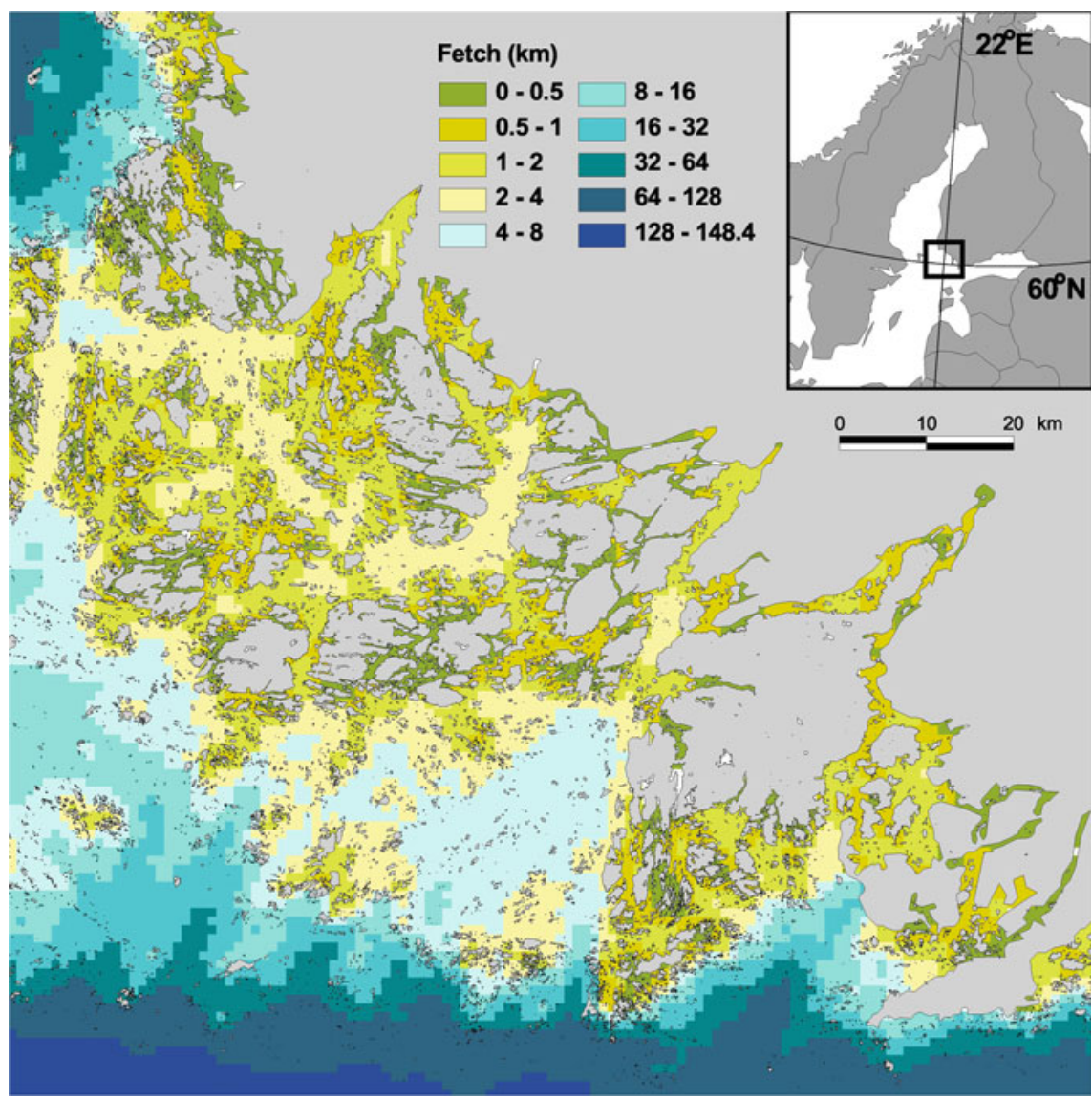

archipelago areas, chlorophyll and humic compounds tend to regulate the underwater light field (Erkkilä and Kalliola 2004; Suominen et al. 2010a). Periods of high run-off and precipitation increase the freshwater input and local turbidity near river mouths.

In the complex archipelago areas, shore openness and the consequent shore sensitivity to storm damage create a mosaic of open and sheltered areas with a gradual transition towards the pelagic environment (Fig. 16.5). In addition to the zonal characteristics of the entire archipelago coast (Häyrén 1900; Granö 1981; Tolvanen and Suominen 2004), the abundance of littoral areas vulnerable to shore disturbance processes results in a variety of local patterns and characteristics. Due to continuous land uplift, the duration of exposure to shore processes for a particular site has been 400-800 years (Pyökäri 1986; Granö and Roto 1989a).

\subsection{Climate Change Effects on Coastal Birds and Seabirds}

Since the 1970s, the effects of climate change on birds have been analysed in a rapidly increasing body of literature (for a review, see Møller et al. 2010). According to the Millennium Ecosystem Assessment, climate change is likely to become one of the most significant drivers of biodiversity loss by the end of this century (Millennium Ecosystem Assessment 2005).

This section reviews the effects of climate change on coastal birds and seabirds in the Baltic Sea. Equally important are climate change effects on the distribution of land birds in the catchment area, but these effects are still to be consistently analysed. Discussion of land birds is therefore limited to a few general references and the chapter focuses on coastal birds and seabirds that rely on the habitats provided by the coasts, archipelagos and open sea areas of the Baltic Sea.

\subsubsection{Coastal Birds and Seabirds as Components of Baltic Sea Ecosystems}

Seabirds and coastal birds are an integral part of coastal and marine ecosystems and link into ecosystems at a number of trophic levels (Tasker and Reid 1997), usually as predators near the tops of food chains. Thus, gulls, ducks and waders can play important roles in the mass and energy fluxes of food webs, as well as in food web control (Moreira 1997; Eybert et al. 2003). Seabird nutrient transport between marine and terrestrial realms may shape entire ecosystems (Croll et al. 2005). 
As an addition to their role in ecosystems, birds provide ecosystem services that benefit humans (Șekercioğlu et al. 2004; Millennium Ecosystem Assessment 2005; Șekercioğlu 2006). In Sweden, Rönnbäck et al. (2007) identified more than forty categories of goods and services provided by coastal ecosystems, including several services connected to coastal birds and seabirds.

\subsubsection{Climate Change Effects}

Climate change may impact coastal birds and seabirds of the Baltic Sea area by affecting water salinity, temperature and acidity, air temperature during breeding and non-breeding seasons, as well as rainfall and windiness. These environmental factors can affect birds directly by causing adult or juvenile mortality or indirectly by altering, for instance, the abundance and quality of food. Climate change also affects physical habitats through sea-level rise, storm events and erosion. Furthermore, climate change may interact with other environmental processes, such as eutrophication. These effects may lead to changes in bird population sizes and distributions during breeding and non-breeding seasons and thus alter the composition of bird communities.

\subsubsection{Salinity}

In the Baltic Sea, changes in salinity can have a cascading effect on food webs through the whole pelagic ecosystem (Hänninen et al. 2003; Wasmund et al. 2011). Some climate change scenarios project a decrease in Baltic Sea salinity, while others project an increase (BACC Author Team 2008; Chap. 13). A fall in salinity would lead to a decrease in marine species and an increase in freshwater species (Möllmann et al. 2005; MacKenzie et al. 2007), while an increase in salinity would cause the reverse. Changes in salinity would probably affect coastal birds and seabirds indirectly, mainly through changes in food availability. For instance, distribution and size of the blue mussel Mytilus edulis are highly dependent on salinity (Westerbom et al. 2008), whereas the Baltic clam Macoma balthica has a greater capacity to acclimatise to highly dilute brackish conditions (Jansen et al. 2009). As it is mediated by food availability, the relationship between salinity and bird populations may not become apparent immediately (Rönkä et al. 2005).

\subsubsection{Water Temperature}

The marine ecosystem is sensitive to changes in water temperature, which can affect the plankton (Dahlgren et al. 2011; Wasmund et al. 2011) as well as fish reproduction and survival (Margonski et al. 2010), and may thus have an impact on the food resources of coastal birds and seabirds. The rise in surface water temperature in the Baltic Sea over the past 100 years (Belkin 2009) may have had significant ecological consequences (MacKenzie and Schiedeck 2007; see also Chaps. 18 and 19).

\subsubsection{Eutrophication and Oxygen Deficiency}

Climatic factors can promote eutrophication by enhancing nutrient inputs through increased run-off and precipitation (Hänninen and Vuorinen 2011). Both eutrophication and the rise in water temperature have caused a reduction in the oxygen content of the Baltic Sea water, which has in turn resulted in negative impacts on some prey items, such as different life stages of the eastern Baltic cod Gadus morhua (Hinrichsen et al. 2011). While some coastal birds might initially benefit from eutrophication, at some point the effects can turn negative (Rönkä et al. 2005).

\subsubsection{Food Web Structure}

Changes in food webs may have severe effects on coastal birds and seabirds at the top of the food chain. Climate change has been shown to affect the populations of oceanic seabirds by diminishing their food resources (Montevecchi and Myers 1997; Barbraud and Weimerskirch 2003). In addition to food abundance, the quality of food items may change (Riou et al. 2011). The low-energy value of fish was considered the cause of a major breeding failure of common guillemots Uria aalge in the North Sea (Wanless et al. 2005). Similarly, Österblom et al. (2001) found a long-term decline in the individual mass of common guillemot Uria aalge chicks when leaving a colony in the Baltic Sea that coincided with a decline in the condition of the sprat Sprattus sprattus. However, on the Norwegian coast, milder winters have been found to increase the availability of fish prey for the lesser black-backed gull Larus fuscus fuscus (Bustnes et al. 2010).

Climate change may also alter predation pressure on birds by facilitating invasions of mammalian predators. In the Baltic Sea area, non-indigenous mammalian predators that may prey on coastal birds and seabirds are mainly the American mink Mustela vison and the raccoon dog Nyctereutes procyonoides. The raccoon dog probably benefits from climate warming (Melis et al. 2010), which may allow it to increase and expand its distribution northwards (Helle and Kauhala 1991; Melis et al. 2010). However, evidence of the raccoon dog's negative impacts on bird populations is still scarce (Kauhala and Kowalczyk 2011). The American mink in turn reduces the breeding densities of several birds nesting on small islands in the Finnish archipelago (Nordström et al. 2002, 2003), but there are few assessments of the possible effects of climate change on its abundance and distribution. In Iceland, climate change events may have contributed to a reduction in the mink population (Magnusdottir 2012) and an American study has shown its sensitivity to hydrological shifts resulting from climate change (Schooley et al. 2012). 


\subsubsection{Weather Conditions}

Climate change may affect the breeding performance of seabirds by altering weather conditions during breeding or by affecting the condition of the birds after winter (Hildén 1964; Milne 1976; Lehikoinen et al. 2006). Weather, especially temperature, rainfall and wind, is important for the breeding success of common eider Somateria mollissima, velvet scoter Melanitta fusca, mute swan Cygnus olor and tufted duck Aythya fuligula (Koskimies 1955; Hildén 1964; Koskimies and Lahti 1964; Koskinen et al. 2003). If climate change increases the frequency of extreme weather events, there may be strong effects on reproductive success.

High temperatures during the breeding season may cause heat stress in adults, particularly in species that make long foraging trips, forcing the other parent to spend extensive periods in continuous nest attendance (Oswald et al. 2011). Climate change can also affect breeding success through complex predator-prey interactions, for instance by changing the availability of prey other than birds (Hario et al. 2009). However, even a severe crash in fledgling production need not affect the size of the future local breeding population (Rönkä et al. 2005).

Severe winters have been suggested to influence populations of the great crested grebe Podiceps cristatus (von Haartman 1945), mute swan (Koskinen et al. 2003; Rönkä et al. 2005), coot Fulica atra (von Haartman 1945, Rönkä et al. 2005), tufted duck (Hildén 1966, Hildén and Hario 1993), mallard Anas platyrhynchos, common eider and common goldeneye Bucephala clangula (Rönkä et al. 2005). Furthermore, high winter mortality has been assumed to be the main reason for the decline in razorbill Alca torda and greater scaup Aythya marila during the Second World War (Hildén and Hario 1993). The effects of cold winters can be additive, and it may take years for a species to recover (Rönkä et al. 2005). Winter severity may also affect the densitydependence of survival (Barbraud and Weimerskirch 2003).

\subsubsection{Sea Ice}

A climate-induced decrease in the ice coverage of the Baltic Sea would improve wintering conditions for Baltic Sea coastal birds and seabirds by alleviating competition for food. In addition, wintering birds would not congregate in areas of intense shipping. This would reduce their vulnerability to oil hazards, which are an important mortality factor for the long-tailed duck Clangula hyemalis (Hario et al. 2009). However, the net effect of climate change on the risk from oil pollution is unclear; while a decrease in ice cover might reduce the risk from oil pollution, an increase in windiness and extreme weather events might enhance it.

\subsubsection{Migration}

Many Baltic Sea coastal birds and seabirds migrate only as far as the western or southern Baltic Sea or the North Sea
(Cramp and Simmons 1977; Pihl et al. 1995; Gilissen et al. 2002). A minor component of the Finnish and Swedish populations of some coastal birds remains in the northern Baltic Sea (Gilissen et al. 2002). Winter severity in the Baltic Sea reflects winter severity in the North Sea and further off the coast of western Europe, as well as in central Europe (Hurrell 1995). Winter severity in western Europe affects the non-breeding survival of several coastal birds and seabirds (Nilsson 1984; Koskinen et al. 2003). In addition to mortality from starvation and cold, severe winters may force birds to migrate further than normal and this incurs extra energy costs. Furthermore, when the Baltic Sea is largely ice-covered, seabirds are forced to feed in small open areas which increases competition for food and possibly the risk of disease (Grenquist 1965; Hario et al. 1995).

Climate change affects the arrival and departure times of migrants (Forchhammer et al. 2002; Jonzén et al. 2002; Hüppop and Hüppop 2003; Lehikoinen et al. 2004; Lehikoinen and Sparks 2010; Lehikoinen and Jaatinen 2011) and the timing of breeding (Forchhammer et al. 1998; Both and Visser 2001; Møller 2002; Sanz 2002). A mismatch between hatching time and resource availability has been observed in passerines (e.g. pied flycatcher Ficedula hypoleuca, Both et al. 2006) as well as in ducks (Oja and Pöysä 2007). Trophic mismatches may cause population declines particularly in long-distance migrants in seasonal habitats (Both et al. 2010). In addition to trophic constraints, longdistance migrants may suffer from increasing competitive pressure by residents and short-distance migrants along with climate change, contributing to population declines in longdistance migrants (Lemoine and Böhning-Gaese 2003).

Climate change may also drive changes in migratory routes, stopover sites and migratory tendencies within species and populations. For instance, delayed departure from breeding areas may be the cause of recently observed northward shifts in wintering ducks (Lehikoinen and Jaatinen 2011). Milder winters may allow birds to winter closer to breeding grounds and thus contribute to higher survival, which has been proposed for the mallard (Gunnarsson et al. 2012). However, temperature may be less important in shaping the wintering distributions of European dabbling ducks than factors such as feeding ecology (Dalby et al. 2013).

Species ranges are expected to move poleward with climate change (Thomas and Lennon 1999; Hickling et al. 2006), and this has already been shown for the breeding ranges of central European and Arctic birds (Brommer et al. 2012). More study species $(41 ; 69 \%)$ shifted their range margin northwards than southwards $(18 ; 31 \%)\left(\mathrm{X}^{2}\right.$, $p=0.00275)$. Only a few range margin shifts were greater than three grid squares. An example of a species with a large shift in the southern border northward is the ruff Philomachus pugnax. Large shifts in the northern border occurred in coot, mute swan, common eider, razorbill and Arctic skua 
Stercorarius parasiticus suggesting range extension as the southern border did not move. The latter three species have extended their range much further north on the Atlantic Ocean and North Sea coasts. It is still unclear if climate change is involved in the range shifts and changes in the area of occupancy of the study species, since at least some of the shifts seem to have other causes.

\subsubsection{Sea Level}

Climate change may also affect the physical and biological features of islands through sea-level rise, storm events and erosion. By 2100, many regions currently experiencing a fall in relative sea level can be expected instead to experience a rise (Chap. 14), reversing current land uplift in Baltic Sea archipelagos. Together with storm events and erosion, sealevel rise could affect the succession in coastal bird and seabird breeding habitats. In addition, climate factors affect the productivity of the vegetation cover, which in turn may influence species richness and distribution, as shown by Eronen et al. (2011) for Finnish land birds.

\subsubsection{New Species}

Climate change may facilitate the settlement of new species that are either spreading to the Baltic Sea area naturally or that have been deliberately or accidentally introduced by humans. The effects of climate change on salinity and water temperature can facilitate invasion by non-indigenous aquatic species, which can cause major changes in nearshore ecosystems (Zaiko et al. 2011) and thus affect the food resources of birds. Climate change may also increase the survival and reproductive prospects of vagrant birds and increase the numbers of, for example, vagrant Siberian birds in Europe (Jiguet and Barbet-Massin 2013).

\subsubsection{Changes in Distribution}

Changes in the occurrence and distribution of bird species can be assessed using bird atlas data, such as the Finnish Bird Atlas data (Väisänen et al. 1998; Valkama et al. 2011). Changes in distribution of Finnish coastal and seabird species were studied by comparing data in the first and second Finnish Bird Atlases (1974-1989) (Väisänen et al. 1998) with those in the third (2006-2010) (Valkama et al. 2011). The data presented here cover 59 species in archipelago and coastal $10 \mathrm{~km}^{2}$ square cells, and to avoid bias from differences in research activity, only those cells where the research activity grade was the same in both data sets were compared.

According to a preliminary analysis (Lehikoinen E unpubl.), the area of occupancy (for a description of this concept see Rassi et al. 2010, p. 31) had contracted for 10 (17\%) study species and expanded for 12 (20\%), while 37 (63 \%) showed no significant change. Species with the largest contractions were the ruff, common pochard Aythya ferina, greater scaup and northern pintail Anas acuta.
Species with the largest expansions were the great cormorant Phalacrocorax carbo, barnacle goose Branta leucopsis, whooper swan Cygnus cygnus, and Canada goose Branta canadensis. Of the species with the largest expansions, the great cormorant settled on the Finnish coast in 1996, the barnacle goose in 1981 and the Canada goose in the 1970s (Valkama et al. 2011).

The observed changes in species distribution and density (e.g. Virkkala and Rajasärkkä 2011) can be contrasted with the projections of European species range shifts by Huntley et al. (2008) using a model based on climate-envelopes. The authors predicted that with the current rate of climate change, bird communities in the Baltic Sea area (including all species) may be among the richest in Europe by 2100 . Baltic Sea countries may experience a loss of some species which would in turn be replaced by particularly southern species. The predictions infer major changes in coastal bird and seabird communities in particular.

\subsubsection{Implications for Seabird Man- agement and Conservation}

The effects of climate change on the breeding and feeding ecology of coastal birds and seabirds may first become visible near the limits of their ranges (Barrett and Krasnov 1996; Montevecchi and Myers 1997). Climate change effects might become discernible relatively early in the ecosystems of the Baltic Sea that can be considered marginal because of its distinctive features.

As integral parts of marine ecosystems, seabirds and coastal birds may fill some of the gaps in knowledge about marine and coastal ecosystems under stress. They may even act as indicators of climate change (Furness and Camphuysen 1997; Rönkä et al. 2005), providing early warnings of unforeseen environmental impacts and means to monitor changes at lower trophic levels. Habitat changes, as well as density and distribution shifts should be taken into consideration in species and habitat protection, including the management of currently protected areas and the planning of future conservation efforts (Virkkala and Rajasärkkä 2011). As climate change is already rapidly reshaping species distributions, ignoring future dynamics could lead to misguided and potentially ineffective conservation decisions (Kujala 2012).

Effective measures for the management and conservation of coastal birds and seabirds and their habitats require insight into their population processes and the factors affecting their distribution and abundance. A coherent monitoring system is needed, addressing population size, reproductive success and mortality (Järvinen 1983; Kilpi 1985; O’Connor 1985; Tiainen 1985; Elmberg et al. 2006; Sutherland 2006; Rönkä et al. 2011). Background data on environmental factors should also be collected. 
Owing to the uncertainties concerning climate change scenarios (see Chaps. 10-14), assessing possible effects on coastal birds and seabirds is challenging. The multiple and partly contradictory effects and possible thresholds in the relationship between environmental drivers and ecosystem change add to the complexity. In addition, differences in the ecology of species must be considered (Rönkä 2008). Due to the many environmental pressures on the Baltic Sea, more studies are needed on the relative effects and possible interactions of different environmental changes, such as climate change and eutrophication (Kotta et al. 2009; Põllumae et al. 2009). In addition, a flyway approach is needed as some effects of climate change may act in breeding or wintering areas far from the Baltic Sea (Hario et al. 2009).

\subsection{Climate Change Effects on Forests and Natural Vegetation}

This section describes the effects of climate change on trees and forests in general-impacts on agriculture and managed forestry are addressed in Chap. 21.

\subsubsection{Effects on Forest Growth}

The overriding impacts of climate change on forest growth within the Baltic Sea basin, after the greater risks of extreme weather events such as prolonged drought, storms and flood (Lindner et al. 2010), are considered to be changing patterns of precipitation, increased carbon dioxide $\left(\mathrm{CO}_{2}\right)$ concentrations and rising temperature. The latter may drive an increase in evapotranspiration and, potentially, increased microbial activity which could cause more rapid decomposition of soil organic matter (Magnani et al. 2007). Increased microbial activity would lead to mineralisation and related fertilising effects which would be especially important at previously nutrient-deficient forest sites. Nitrogen emissions from human activities are already having potential fertilising effects so it is difficult to isolate improved nitrogen availability due to higher temperatures. Nevertheless, the end result is expected to be increased tree growth in forests, with the impact greatest at high latitudes and on sites of historical nutrient deficiency (Burschel and Huss 1997; Dengler 1992). Although understanding of nutrient dynamics at high latitudes is limited (Gundale et al. 2011), it seems likely that rising temperature is the major driver (Karjalainen 1996a).

Schulze et al. (2009) stated that at any one moment, the rate of carbon uptake at a particular site would depend on the age composition and density of the stand. They also stated that forest management influences growth rates by controlling species composition and stand density and that management practices have changed over recent decades. Additional factors that might influence forest growth rates are increased temperature and $\mathrm{CO}_{2}$ concentration or nitrogen deposition from the atmosphere. According to Körner et al. (2005), increased $\mathrm{CO}_{2}$ concentration alone would not cause increased growth, which assumes that other limiting factors such as nutrient deficiency may dominate. Similarly, Magnani et al. (2007) concluded that forest net carbon sequestration is overwhelmingly driven by nitrogen deposition, largely from human activities. Nevertheless, de Vries et al. (2009) stressed the high uncertainties related to carbon sequestration per unit weight nitrogen addition.

Pussinen et al. (2009) saw a meaningful increase in growth rates in forests in Scandinavian countries and Finland of up to $75 \%$ in their models compared to a scenario without climate change. In more detail, Karjalainen (1996a) described a model-estimated (gap-type forest model interfaced with a wood product model) increase in carbon sequestration in Scots pine Pinus sylvestris, Norway spruce Picea abies and silver birch Betula pendula stands over 150 years on medium fertile sites in northern and southern Finland (Table 16.2). It is clear that in relative terms, boreal forest stands benefit more from climate change than temperate forest stands. Similar results were found by Alam et al. (2008) who showed, using an ecosystem model, that climate change may substantially increase the growth, timber production and carbon stocks of forest stands. They found the greatest relative change in northern Finland (north of $64^{\circ} \mathrm{N}$ ) with growth increasing by $75-78 \%$, timber production by $59-70 \%$ and carbon stocks by $21-23 \%$. Increases in southern Finland (south of $64^{\circ} \mathrm{N}$ ) were lower at $37-45,23-40$ and $8-10 \%$, respectively, although the absolute (mean) values were higher.

Table 16.2 Projected changes in net carbon sequestration (150-year average value, $\mathrm{Mg} \mathrm{C}_{\mathrm{Ca}}{ }^{-1} \mathrm{year}^{-1}$ ) due to climate change over the period 1990-2140 (Karjalainen 1996a)

\begin{tabular}{lllll}
\hline Species & Northern Finland & & \multicolumn{2}{l}{ Southern Finland } \\
\cline { 2 - 5 } & Current climate & Future climate & Current climate & Future climate \\
\hline Scots pine & 1.10 & $1.42(+29 \%)$ & 0.78 & $0.84(+8 \%)$ \\
\hline Norway spruce & 0.69 & $0.99(+44 \%)$ & 0.96 & $0.32(-67 \%)$ \\
\hline Silver birch and Pubescent birch & 0.43 & $0.60(+40 \%)$ & 0.64 & $0.92(+44 \%)$ \\
\hline
\end{tabular}


Nabuurs et al. (2008) and the first assessment of climate change in the Baltic Sea area (BACC Author Team 2008) reviewed the sensitivity of the main Baltic tree species to climate change. The BACC assessment concluded that coniferous species (Scots pine and Norway spruce) respond positively to rising temperature by showing higher stem growth. This is especially the case for the higher latitudes where temperature and nutrient deficiencies are limiting factors, and in general where precipitation is not limiting (Mäkipää et al. 1998; Bergh et al. 2003; Lindner et al. 2010). However, in the temperate forest zone (in the southern part of the Baltic Sea basin), a potential fertilisation effect by increased $\mathrm{CO}_{2}$ concentrations and enhanced nitrogen availability seems to be dominated by water stress, although the effect of elevated $\mathrm{CO}_{2}$ concentrations may counteract such potential negative effects (BACC Author Team 2008). A stronger potential fertilisation effect of increased $\mathrm{CO}_{2}$ concentrations can be expected in northern latitudes, where increased precipitation is projected.

Birch (Betula spp.), the main deciduous species in the boreal zone responds to rising temperature in the same manner as spruce and pine, but is less sensitive to changes in precipitation. In contrast, oak (Quercus spp.) and common beech (Fagus sylvatica) show a generally strong response to precipitation changes in temperate zones. While the growth of beech generally responds negatively to increased temperature, oak shows a weak positive response (BACC Author Team 2008).

Karjalainen (1996b) reported similar conclusions, reporting increased forest ecosystem production under a changing climate in northern Finland and a decline in Norway spruce in southern Finland. The carbon sequestration potential of Norway spruce declined sharply in southern Finland. This corresponds to the results of the first BACC assessment (BACC Author Team 2008) and of Kellomäki and Kolström (1994) and reflects the major impact of water stress (compare Bergh et al. 2003; Lindner et al. 2010).

Similar results were reported by Köhl et al. (2010) for temperate zones in north-eastern Germany: the authors found severe challenges to tree species sensitive to water stress (i.e. in this study, Norway spruce) with model simulations over a 100 -year period projecting a decline in those species in north-eastern Germany for all scenarios.

With a focus on changing patterns of precipitation and temperature, Lasch et al. (2002) reported the likely future effects of climate change on forests in the Federal State of Brandenburg (Germany) - which can be used as a proxy for the south-westernmost part of the Baltic Sea basin. The results suggested that warming would lead to a shift in the natural species composition towards more drought tolerant species, that the diversity of the forests would decline and that groundwater recharge would decrease.

\subsubsection{Effects on Natural Vegetation}

To investigate the possible impacts of climate change on natural vegetation, studies were undertaken using the IPCC SRES scenarios for the twenty-first century. The studies indicated that species could shift, with a tendency for species to shift northwards and eastwards in the Baltic Sea basin (Ohlemüller et al. 2006; Wolf et al. 2007). Hickler et al. (2012) used a vegetation model to project changes in Europe's natural vegetation and showed that a considerable part of the Baltic Sea basin could undergo a change in species composition, with a predominant northward shift in the hemiboreal and temperate mixed forests. Arctic and alpine regions showed particularly large changes. Similarly, Thuiller et al. (2005) reported high sensitivity for plant diversity in the Arctic and mountainous regions. Species loss was projected to be greater in the southern part of the Baltic Sea basin than the northern, but the region has high potential for species to migrate in from the south (Thuiller et al. 2005). However, a study by Chytrý et al. (2012) which separated different land-use classes showed that forests were generally least sensitive to plant species migration.

\subsubsection{Effects on Carbon Storage}

For managed forests, the Baltic Sea basin has been projected to see a rise in annual increment in carbon sequestration for all SRES scenarios (Nabuurs et al. 2002; Eggers et al. 2008). This would cause the relatively low net ecosystem productivity of forestry in the region (Luyssaert et al. 2010; Bellassen et al. 2011) to approach that of central and southern Europe.

In general, terrestrial carbon storage is anticipated to increase in the Baltic Sea catchment (Wolf et al. 2007; Zaehle et al. 2007; Roderfeld et al. 2008) although higher temperatures have the potential to increase respiration and thereby loss of carbon (Piao et al. 2008). The greatest uncertainties for the carbon balance concern interactions with nitrogen (Churkina et al. 2010), although reduced nitrogen deposition might be offset by more favourable climatic conditions for plant growth in the future (de Vries and Posch 2011).

Land-use change can play an important role in the terrestrial carbon cycle (Zaehle et al. 2007) and can have both positive and negative impacts on carbon storage.

\subsection{Conclusion}

This chapter describes the impacts of climate change on the coastal and terrestrial ecosystems of the Baltic Sea basin. The presence of fragmented and geomorphologically 
complex archipelago coasts is a particular feature of the central and northern part of the Baltic Sea. Archipelagos have high value for biodiversity due to the 'edge effect' and to the high number of different habitats. On the other hand, archipelago ecosystems are vulnerable to climate-mediated changes in the environment. A special characteristic of the Baltic Sea region is post-glacial land uplift. Together with climatic change, land uplift creates a complex situation where plant and animal communities must adapt to a new environment modified by both of these factors. The combined effects of climate change and land uplift on coastal ecosystems have been little studied and need particular emphasis in the future.

Warmer terrestrial ecosystems and warmer coastal sea water affect the northward migration of terrestrial and aquatic species and result in longer reproductive periods for coastal fauna and flora. The biodiversity of the Baltic Sea is particularly sensitive to changes in salinity, which can have a cascading effect on food webs and interaction between aquatic and terrestrial ecosystems. The effects of climate change on salinity and water temperature can facilitate invasion by non-indigenous aquatic bird species, such as cormorants, which can cause major changes in coastal bird communities. The climate-mediated changes can also facilitate the invasion of mammalian predators which can cause major changes in coastal and archipelago ecosystems.

The positive impacts of climate change on forest growth will continue. In relative terms, boreal forest stands benefit more from the climate change than temperate forest stands.

The Baltic Sea drainage basin is expected to undergo a change in the species composition of natural vegetation, with a predominantly northward shift of the hemiboreal and temperate mixed forests. Projected losses of species are greater in the southern part of the Baltic Sea basin than in the north.

Terrestrial carbon storage is likely to increase in the Baltic Sea catchment area. However, land-use change can play an important role in the terrestrial carbon cycle and have both positive and negative impacts on carbon storage.

Open Access This chapter is distributed under the terms of the Creative Commons Attribution Noncommercial License, which permits any noncommercial use, distribution, and reproduction in any medium, provided the original author(s) and source are credited.

\section{References}

Alam A, Kilpeläinen A, Kellomäki S (2008) Impacts of thinning on growth, timber production and carbon stocks in Finland under changing climate. Scand J Forest Res 23:501-512

BACC Author Team (2008) Assessment of Climate Change for the Baltic Sea Basin. Springer, Berlin, Heidelberg
Barbraud C, Weimerskirch H (2003) Climate and density shape population dynamics of a marine top predator. Proc Roy Soc Lond B 270:2111-2116

Barrett RT, Krasnov YV (1996) Recent responses to changes in stocks of prey species by seabirds breeding in the southern Barents Sea. ICES J Mar Sci 53:713-722

Bartley J, Buddemeier R, Bennett D. (2001) Coastline complexity: a parameter for functional classification of coastal environments. J Sea Res 46:87-97

Belkin I (2009) Rapid warming of large marine ecosystems. Progr Oceanogr 81:207-213

Bellassen V, Viovy N, Luyssaert S, Maire G, Schelhaas M-J, Ciais P (2011) Reconstruction and attribution of the carbon sink of European forests between 1950 and 2000. Global Change Biol 17:3274-3292

Bergh J, Freeman M, Sigurdsson BD, Kellomäki S, Laitinen K, Niinistö S, Peltola H, Linder S (2003) Modelling the short-term effects of climate change on the productivity of selected tree species in Nordic countries. Forest Ecol Manag 183:327-340

Bird E (2000) Coastal Geomorphology: An Introduction. Wiley, Chichester

Björck S (1995) A review of the history of the Baltic Sea, 13.0-8.0 ka BP. Quaternary Int 27:19-40

Boström C, O'Brien K, Roos C, Ekebom J (2006) Environmental variables explaining structural and functional diversity of seagrass macrofauna in an archipelago landscape. J Exp Mar Biol Ecol 335:52-73

Both C, Visser ME (2001) Adjustment to climate change is constrained by arrival date in a long-distance migrant bird. Nature 411:296-298

Both C, Bouwhuis S, Lessells CM, Visser ME (2006) Climate change and population declines in a long-distance migratory bird. Nature 441:81-83

Both C, Van Turnhout CAM, Bijlsma RG, Siepel H, Van Strien AJ, Foppen RPB (2010) Avian population consequences of climate change are most severe for long-distance migrants in seasonal habitats. Proc Roy Soc B 277:1259-1266

Brommer JE, Lehikoinen A, Valkama J (2012) The breeding ranges of Central European and Arctic bird species move poleward. Plos ONE 7:e43648

Burrows M, Schoeman D, Buckley L et al (2011) The pace of shifting climate in marine and terrestrial ecosystems. Science 334:652-655

Burschel P, Huss J (1997) Grundriß des Waldbaus. 2nd Edition. Parey, Berlin

Bustnes JO, Anker-Nilssen T, Lorentsen S-H (2010) Local and largescale climatic variables as predictors of the breeding numbers of endangered lesser black-backed Gulls on the Norwegian coast. J Ornithol 151:19-26

Chapin F, Danell K, Elmqvist T, Folke C, Fresco N (2007) Managing climate change impacts to enhance the resilience and sustainability of Fennoscandian forests. Ambio 36:528-533

Churkina G, Zaehle S, Hughes J, Viovy N, Chen Y, Jung M, Heumann BW, Ramankutty N, Heimann M, Jones C (2010) Interactions between nitrogen deposition, land cover conversion, and climate change determine the contemporary carbon balance of Europe. Biogeosciences 7:2749-2764

Chytrý M, Wild J, Pyšek P, Jarošík V, Dendoncker N, Reginster I, Pino J, Maskell LC, Vilà M, Pergl J, Kühn I, Spangenberg JH, Settele J (2012) Projecting trends in plant invasions in Europe under different scenarios of future land-use change. Global Ecol Biogeogr 21:75-87

Cramp S, Simmons KEL (1977) Handbook of the Birds of Europe, the Middle East and North Africa. The Birds of the Western Palearctic, Vol I, Ostrich to Ducks. Oxford University Press, Oxford

Croll DA, Maron JL, Estes JA, Danner EM, Byrd GV (2005) Introduced predators transform subarctic islands from grassland to tundra. Science 307:1959-1961 
Dalby L, Fox AD, Petersen IK, Delany S, Svenning J-C (2013) Temperature does not dictate the wintering distributions of European dabbling duck species. Ibis 155:80-88

Dahlgren K, Eriksson Wiklund A-K, Andersson A (2011) The influence of autotrophy, heterotrophy and temperature on pelagic food web efficiency in a brackish water system. Aquat Ecol 45:307-323

de Vries W, Posch M (2011) Modelling the impact of nitrogen deposition, climate change and nutrient limitations on tree carbon sequestration in Europe for the period 1900-2050. Environ Pollut 159:2289-2299

de Vries W, Solberg S, Dobbertin M, Sterba H, Laubhann D, van Oijen M, Evans C, Gundersen P, Kros J, Wamelink GWW, Reinds GJ, Sutton MA (2009) The impact of nitrogen deposition on carbon sequestration by European forests and heathlands. Forest Ecol Manag 258:1814-1823

Dengler A (1992) Waldbau auf ökologischer Grundlage. Erster Band: Der Wald als Vegetationsform und seine Bedeutung für den Menschen. Parey, Berlin

Donner R, Ehrcke R, Barbossa S, Wagner J, Donges J, Kurths J (2012) Spatial patterns of linear and nonparametric long-term trends in Baltic sea level variability. Nonlin Processes Geophys 19:95-111

EEA (2006) CORINE Land Use Classification. European Environment Agency

Eggers J, Lindner M, Zudin S, Zaehle S, Liski J (2008) Impact of changing wood demand, climate and land use on European forest resources and carbon stocks during the 21st century. Global Change Biol 14:2288-2303

Ekebom J, Laihonen P, Suominen T (2003) A GIS-based step-wise procedure for assessing physical exposure in fragmented archipelagos. Estuar Coast Shelf Sci 57:887-898

Elmberg J, Nummi P, Pöysä H, Sjöberg K, Gunnarsson G, Clausen P, Guillemain M, Rodrigues D, Väänänen V-M (2006) The scientific basis for new and sustainable management of migratory European ducks. Wildlife Biol 12:121-127

Eriksson B, Sandström A, Isæus M, Schreiber H, Karås P (2004) Effects of boating activities on aquatic vegetation in the Stockholm archipelago, Baltic Sea. Estuar Coast Shelf Sci 61:339-349

Erkkilä A, Kalliola R (2004) Patterns and dynamics of coastal waters in multi-temporal satellite images: support to water quality monitoring in the Archipelago Sea, Finland. Estuar Coast Shelf Sci 60:165-177

Eronen M (2005) Land uplift: virgin land from the sea. In: Seppälä M (ed), The Physical Geography of Fennoscandia. Oxford University Press, Oxford, p 17-34

Eronen JT, Puolamäki K, Heikinheimo H, Lokki H, Venäläinen A, Mannila H, Fortelius M (2011) The effect of scale, climate and environment on species richness and spatial distribution of Finnish birds. Ann Zool Fenn 48:257-274

Eybert M-C, Geslin T, Questiau S, Feunteun E (2003) Shorebird community variations indicative of a general perturbation in the Mont Saint-Michel bay (France). C R Biol 326(S1):140-147

Fairbridge R (2004) Classification of coasts. J Coast Res 20:155-165

Finkl C (2004) Coastal classification: systematic approaches to consider in the development of a comprehensive scheme. J Coast Res 20:166-213

FMI (1991) Climatological Statistics in Finland 1961-1990. Supplement of the Meteorological Yearbook of Finland, part 1 vol 1 , Finnish Meteorological Institute

Forbes D, Taylor R (1994) Ice in the shore zone and the geomorphology of cold coasts. Progr Phys Geogr 18:59-89

Forchhammer MC, Post E, Stenseth NC (1998) Breeding phenology and climate. Nature 391:29-30

Forchhammer MC, Post E, Stenseth NC (2002) North Atlantic Oscillation timing of long- and short-distance migration. J Animal Ecol 71:1002-1014
Frisén R, Johansson C, Suominen V (2005) Archipelagos in the Baltic Sea. In: Seppälä M (ed), The Physical Geography of Fennoscandia, Oxford University Press, Oxford, p 267-281

Furman E, Dahlström H, Hamari R (1998) Itämeri - luonto ja ihminen. Otava, Keuruu

Furness RW, Camphuysen CJ (1997) Seabirds as monitors of the marine environment. ICES J Mar Sci 54:726-737

Gilissen N, Haanstra L, Delany S, Boere G, Hagemeijer W (2002) Numbers and distribution of wintering waterbirds in the Western Palearctic and Southwest Asia in 1997, 1998 and 1999. Results from the International Waterbird Census. Wetlands International Global Series No 11

Granö O (1981) The zone concept applied to the Finnish coast in the light of scientific traditions. Fennia 159:63-68

Granö O, Roto M (1986) Coasts. In: Alalammi P (ed), Geomorphology. Atlas of Finland 121-122, 5-8. Maanmittaushallitus \& the Geographical Society of Finland, Helsinki

Granö O, Roto M (1989a) The duration of shore exposure along the emerging Finnish coast. J Coast Res 5:49-55

Granö O, Roto M (1989b) Zonality in the Finnish coastal environment. Essener Geographische Arbeiten 18:269-281

Granö O, Roto M, Laurila L (1999) Environment and land use in the shore zone of the coast of Finland. Publicationes instituti geographici universitatis Turkuensis 160

Grenquist P (1965) Changes in abundance of some duck and sea-bird populations off the coast of Finland 1949-1963. Finn Game Res 27:1-114

Gundale MJ, Deluca TH, Nordin A (2011) Bryophytes attenuate anthropogenic nitrogen inputs in boreal forests. Global Change Biol 17:2743-2753

Gunnarsson G, Waldenström J, Fransson T (2012) Direct and indirect effects of winter harshness on the survival of Mallards Anas platyrhynchos in northwest Europe. Ibis 154:307-317

Haapala J, Leppäranta M (1997) The Baltic Sea ice season and the changing climate. Boreal Environ Res 2:93-108

Hammarklint T (2009) Swedish sea level series - a climate indicator. Swedish Meteorological and Hydrological Institute

Hänninen J, Vuorinen I (2011) Time-varying parameter analysis of the Baltic Sea freshwater runoffs. Environ Model Assess 16:53-60

Hänninen J, Vuorinen I, Kornilovs G (2003) Atlantic climatic factors control decadal dynamics of a Baltic Sea copepod Temora longicornis. Ecography 26:672-678

Hario M, Lehtonen JT, Hollmén T (1995) Role, if any, of the acanthocephalan worm Polymorphus minutus in common eider mortality. Suom Riista 41:21-26 (in Finnish, English summary)

Hario M, Rintala J, Nordenswan G (2009) Dynamics of wintering longtailed ducks in the Baltic Sea - the connection with lemming cycles, oil disasters, and hunting. Suom Riista 55: 83-96 (in Finnish, English summary)

Häyrén E (1900) Längs-zonerna i Ekenäs skärgård. Geografiska Föreningens Tidskrift 12:222-234

Heino R (1994) Climate in Finland during the period of meteorological observation. Finnish Meteorological Institute Contributions 12

HELCOM (2007) Climate Change in the Baltic Sea Area - HELCOM Thematic Assessment in 2007. Baltic Sea Environmental Proceedings No 111

HELCOM (2009) Eutrophication in the Baltic Sea - An integrated thematic assessment of the effects of nutrient enrichment and eutrophication in the Baltic Sea region. Baltic Sea Environment Proceedings 115

HELCOM (2012) HELCOM Map and Data service. http://maps. helcom.fi/website/mapservice/

Helle E, Kauhala K (1991) Distribution history and present status of the raccoon dog in Finland. Holarctic Ecol 14:278-286 
Hickler T, Vohland K, Feehan J, Miller PA, Smith B, Costa L, Giesecke T, Fronzek S, Carter TR, Cramer W, Kühn I, Sykes MT (2012) Projecting the future distribution of European potential natural vegetation zones with a generalized, tree species-based dynamic vegetation model. Global Ecol Biogeogr 21:50-63

Hickling R, Roy DB, Hill JK, Fox R, Thomas CD (2006) The distributions of a wide range of taxonomic groups are expanding polewards. Glob Change Biol 12:450-455

Hildén O (1964) Ecology of duck populations in the island group of Valassaaret, Gulf of Bothnia. Ann Zool Fenn 1:153-279

Hildén O (1966) Changes in the bird fauna of Valassaaret, Gulf of Bothnia, during recent decades. Ann Zool Fenn 3:245-269

Hildén O, Hario M (1993) Muuttuva saaristolinnusto. Forssan kirjapaino, Forssa

Hinrichsen H-H, Huwer B, Makarchouk A, Petereit C, Schaber M, Voss R (2011) Climate-driven long-term trends in Baltic Sea oxygen concentrations and the potential consequences for eastern Baltic cod (Gadus morhua). ICES J Mar Sci 68:2019-2028

Huntley B, Green R, Collingham Y, Willis SG (2008) A Climatic Atlas of European Breeding Birds. Lynx Edicions, Barcelona

Hüppop O, Hüppop K (2003) North Atlantic Oscillation and timing of spring migration in birds. Proc Roy Soc Lond B 270(1512): 233-240

Hurrell JW (1995) Decadal trends in the North Atlantic Oscillation: regional temperatures and precipitation. Science 269:676-679

Jaatinen S (1984) Geographical research on the archipelagoes of Finland. Fennia 162:1:81-101

Jansen JM, Koutstaal A, Bonga SW, Hummel H (2009) Salinity-related growth rates in populations of the European clam Macoma balthica and in field transplant experiments along the Baltic Sea salinity gradient. Mar Freshwater Behaviour Physiol 42:157-166

Järvinen O (1983) How should a Finnish monitoring system of bird populations be implemented? Ornis Fennica 60:126-128 (in Finnish, English abstract)

Jiguet F, Barbet-Massin M (2013) Climate change and rates of vagrancy of Siberian bird species to Europe. Ibis 155:194-198

Johansson MM, Kahma KK, Boman H, Launianen J (2004) Scenarios for the sea level on the Finnish coast. Boreal Environ Res 9:153-166

Jonzén N, Hedenström A, Hjort C, Lindström Å, Lundberg P, Andersson A (2002) Climate patterns and the stochastic dynamics of migratory birds. Oikos 97:329-336

Kakkuri J (1987) Character of the Fennoscandian land uplift in the 20th century. Geological Survey of Finland Special paper 2, p 15-20

Karjalainen T (1996a) Dynamics and potentials of carbon sequestration in managed stands and wood products in Finland under changing climate conditions. Forest Ecol Manag 80:113-132

Karjalainen T (1996b) The carbon sequestration potential of unmanaged forest stands in Finland under changing climate conditions. Biomass Bioenerg 10:313-329

Kauhala K, Kowalczyk R (2011) Invasion of the raccoon dog Nyctereutes procyonoides in Europe: History of colonization, features behind its success, and threats to native fauna. Current Zoology 57:584-598

Kellomäki S, Kolström M (1994) The influence of climate change on the productivity of Scots pine, Norway spruce, Pendula birch and Pubescent birch in southern and northern Finland. Forest Ecol Manag 65:201-217

Kilpi M (1985) Archipelago bird populations in Finland: monitoring and recent changes. Ornis Fennica 62:42-46

Kirk J (2011) Light and photosynthesis in aquatic ecosystems. $3^{\text {rd }}$ ed, Cambridge University Press, Cambridge

Köhl M, Hildebrandt R, Olschofsky K, Köhler R, Rötzer T, Mette T, Pretzsch H, Köthke M, Dieter M, Abiy M, Makeschin F, Kenter B (2010) Combating the effects of climate change on forests by mitigation strategies. Carbon Bal Manag 5:8
Kont A, Ratas U, Puurmann E (1997). Sea-level rise impact on coastal areas of Estonia. Climatic Change 36:175-184

Kont A, Jaagus J, Aunap R (2003) Climate change scenarios and the effect of sea-level rise for Estonia. Global Planet Change 36:1-15

Körner C, Asshoff R, Bignucolo O, Hättenschwieler S, Keel SG, Pela'ez-Riedl S, Pepin S, Siegwolf RTW, Zotz G (2005) Carbon flux and growth in mature deciduous forest trees exposed to elevated $\mathrm{CO}_{2}$. Science 309:1360-1362

Koskimies J (1955) Juvenile mortality and population balance in the velvet scoter (Melanitta fusca) in maritime conditions. Acta XI Congr Int Orn Basel 1954:476-479

Koskimies J, Lahti L (1964) Cold hardiness of the newly hatched young in relation to ecology and distribution in ten species of European ducks. Auk 81:281-307

Koskinen P, Saari L, Nummi P, Pellikka J (2003) Population density and weather affect the breeding success of mute swan in southern Finland. Suom Riista 49:17-24 (in Finnish, English summary)

Kotta J, Kotta I, Simm M, Põllupüü M (2009) Separate and interactive effects of eutrophication and climate variables on the ecosystem elements of the Gulf of Riga. Estuar Coast Shelf Sci 84:509-518.

Kujala H (2012) Climate change, species range shifts and uncertainty a new era of conservation planning. University of Helsinki, Finland

Lasch P, Lindner M, Erhard M, Suckow F, Wenzel A (2002) Regional assessment on structure and functions under climate change - the Brandenburg case study. Forest Ecol Manag 162:73-86

Lehikoinen A, Jaatinen K (2011) Delayed autumn migration in northern European waterfowl. J Ornithol 153:563-570

Lehikoinen E, Sparks TH (2010) Changes in migration. In: Møller AP, Fiedler W, Berthold P (eds), Birds and Climate Change. Oxford University Press, Oxford, p 89-112

Lehikoinen E, Sparks T, Zalakevicius M (2004) Arrival and departure dates. Adv Ecol Res 35:1-31

Lehikoinen A, Kilpi M, Öst M (2006) Winter climate affects subsequent breeding success of common eiders. Global Change Biol 12:1355-1365

Lemoine N, Böhning-Gaese K (2003) Potential impact of global climate change on species richness of long-distance migrants. Conservat Biol 17:577-586

Leppäranta M, Myrberg K (2009) Physical Oceanography of the Baltic Sea. Springer, Berlin

Lindner M, Maroschek M, Netherer S, Kremer A, Barbati A, GarciaGonzalo J, Seidl R, Delzon S, Corona P, Kolström M, Lexer M and Marchetti M (2010) Climate change impacts, adaptive capacity, and vulnerability of European forest ecosystems. Forest Ecol Manag 259:698-709

Lundberg C, Lönnroth M, von Numers M, Bonsdorff E (2005) A multivariate assessment of coastal eutrophication. Examples from the Gulf of Finland, northern Baltic Sea. Mar Pollut Bull 50:1185-1196

Luyssaert S, Ciais P, Piao SL et al (2010) The European carbon balance. Part 3: forests. Global Change Biol 16:1429-1450

MacKenzie BR, Schiedeck D (2007) Daily ocean monitoring since 1860 s shows record warming on northern European seas. Global Change Biol 13:1335-1347

MacKenzie BR, Gíslason H, Mollmann C, Koster FW (2007) Impact of 21 st century climate change on the Baltic Sea fish community and fisheries. Global Change Biol 13:1348-1367

Magnani F, Mencuccini M, Borghetti M et al (2007) The human footprint in the carbon cycle of temperate and boreal forests. Nature 447:848-850

Magnusdottir R (2012) Diet changes in American mink population in Iceland. In: Ecology: Fundamental Science of the Biosphere. Annual conference of the Ecological Society of Australia, 3-7 December 2012

Mäkipää R, Karjalainen T, Pussinen A, Kukkola M (1998) Effects of nitrogen fertilization on carbon accumulation in boreal forests: 
Model computations compared with the results of long-term fertilization experiments. Chemosphere 36:1155-1160

Margonski P, Hansson S, Tomczak MT, Grzebielec R (2010) Climate influence on Baltic cod, sprat, and herring stock-recruitment relationships. Progr Oceanogr 87:277-288

Melis C, Herfindal I, Kauhala K, Andersen R, Høgda K-A (2010) Predicting animal performance through climatic and plant phenology variables: The case of an omnivore hibernating species in Finland. Mamm Biol 75:151-159

Millennium Ecosystem Assessment (2005) Ecosystems and Human Well-being: Synthesis. Island Press, Washington DC

Milne H (1976) Body weight and carcass composition of the Common Eider. Wildfowl 27:115-122

Møller AP (2002) North Atlantic Oscillation (NAO) effects of climate on the relative importance of first and second clutches in a migratory passerine bird. J Anim Ecol 71:201-210

Møller AP, Fiedler W, Berthold P (eds) (2010) Birds and Climate Change. Oxford University Press, Oxford

Möllmann C, Kornilovs G, Fetter M, Köster FW (2005) Climate, zooplankton, and pelagic fish growth in the central Baltic Sea. ICES J Mar Sci 62:1270-1280

Montevecchi WA, Myers RA (1997) Centurial and decadal oceanographic influences on changes in northern gannet populations and diets in the north-west Atlantic: implications for climate change. ICES J Mar Sci 54:608-614

Moreira F (1997) The importance of shorebirds to energy fluxes in a food web of a south European estuary. Estuar Coast Shelf Sci 44:67-78

Munsterhjelm R (1997) The aquatic macrophyte vegetation of flads and gloes, S. coast of Finland. Acta Bot Fennica 157

Murtojärvi M, Suominen T, Tolvanen $\mathrm{H}$, Leppänen V, Nevalainen O (2007) Quantifying distances from points to polygons - applications in determining fetch in coastal environments. Comput Geosci 33:843-852

Myrberg K, Leppäranta M, Kuosa H (2006) Itämeren fysiikka, tila ja tulevaisuus. Helsinki University Press

Nabuurs G-J, Pussinen ARI, Karjalainen T, Erhard M, Kramer K (2002) Stemwood volume increment changes in European forests due to climate change - a simulation study with the EFISCEN model. Global Change Biol 8:304-316

Nabuurs GJ, Thürig E, Heidema N, Armolaitis K, Biber P, Cinciala E, Kaufmann E, Mäkipää R, Nilsen P, Petritsch R, Pristova T, Rock J, Schelhaas MJ, Sievanen R, Somogyi Z, Vallet P (2008): Hotspots of the European forest carbon cycle. Forest Ecol Manag 256:194-200

Neumann T, Friedland R (2011) Climate change impacts on the Baltic Sea. In: Schernewski G, Hofstede J, Neumann T (eds) Global Change and the Baltic Sea Coastal Zones. Springer, Dordrecht, vol $1, \mathrm{p} 23-32$

Nilsson L (1984) The impact of hard winters on waterfowl populations of south Sweden. Wildfowl 35:71-80

Nordström M, Högmander J, Nummelin J, Laine J, Laanetu N, Korpimäki E (2002) Variable responses of waterfowl breeding populations to long-term removal of introduced American mink. Ecography 25:385-394

Nordström M, Högmander J, Nummelin J, Laine J, Laanetu N, Korpimäki E (2003) Effects of feral mink removal on seabirds, waders and passerines on small islands in the Baltic Sea. Biol Conservat 109:359-368

O'Connor RJ (1985) Long-term monitoring of British bird populations. Ornis Fennica 62:73-79

Ohlemüller R, Gritti ES, Sykes MT, Thomas CD (2006) Towards European climate risk surfaces : the extent and distribution of analogous and non-analogous climates 1931-2100. Global Ecol Biogeogr 15:395-405

Oja H, Pöysä H (2007) Spring phenology, latitude, and the timing of breeding in two migratory ducks: implications of climate change impacts. Ann Zool Fenn 44:475-485
Omstedt A, Nyberg L (1997) Response of Baltic Sea ice to seasonal, interannual forcing and climate change. Tellus A 48:644-662

Omstedt A, Pettersen C, Rodhe J, Winsor P (2004) Baltic Sea climate: $200 \mathrm{yr}$ of data on air temperature, sea level variations, ice cover, and atmospheric circulation. Clim Res 25:205-216

Österblom H, Bignert A, Fransson T, Olsson O (2001) A decrease in fledging body mass in common guillemot Uria aalge chicks in the Baltic Sea. Mar Ecol Progr 224:305-309

Oswald SA, Huntley B, Collingham YC, Russell DJF, Anderson BJ, Arnold JM, Furness RW, Hamer KC (2011) Physiological effects of climate on distributions of endothermic species. J Biogeogr 38: 430-438

Piao S, Ciais P, Friedlingstein P, Peylin P, Reichstein M, Luyssaert S, Margolis H, Fang J, Barr A, Chen A, Grelle A, Hollinger DY, Laurila T, Lindroth A, Richardson AD, Vesala T (2008) Net carbon dioxide losses of northern ecosystems in response to autumn warming. Nature 451:49-52

Pihl S, Durinck J, Skov H (1995) Midwinter waterbird counts in the Baltic Sea, 1993. Suom Riista 41:27-34 (in Finnish, English summary)

Põllumae A, Kotta J, Leisk U (2009) Scale-dependent effects of nutrient loads and climatic conditions on benthic and pelagic communities in the Gulf of Finland. Marine Ecology - An Evolutionary Perspective 30(S1):20-32

Pussinen A, Nabuurs GJ, Wieggers HJJ, Reinds GJ, Wamelink GWW, Kros J, Mol-Dijkstra JP, de Vries W (2009). Modelling long-term impacts of environmental change on mid- and high-latitude European forests and options for adaptive forest management. Forest Ecol Manag 258:1806-1813

Pyökäri M (1986) Relation of grain-size distribution to sediment transport in shore zones, SW Finnish archipelago. Ann Acad Sci Fenn A III 141:6-34

Rassi P, Hyvärinen E, Juslén A, Mannerkoski I (eds) (2010) The 2010 Red List of Finnish Species. Ympäristöministeriö \& Suomen ympäristökeskus, Helsinki www.ymparisto.fi/download.asp? contentid=123016\&lan=fi (accessed 19 March 2012)

Richter A, Groh A, Dietrich R (2012) Geodetic observation of sea-level change and crustal deformation in the Baltic Sea region. Phys Chem Earth A/B/C 53-54:43-53

Riou S, Gray CM, Booke MD, Quillfeldt P, Masello JF, Perrins C, Hamer KC (2011) Recent impacts of anthropogenic climate change on a higher marine predator in western Britain. Mar Ecol Prog Ser 422:105-112

Roderfeld H, Blyth E, Dankers R, Huse G, Slagstad D, Ellingsen I, Wolf A, Lange M (2008) Potential impact of climate change on ecosystems of the Barents Sea Region. Climatic Change 87:283-303

Rönkä M (2008) Assessment of coastal bird populations and habitats on the Finnish coast of the Baltic Sea: Implications for monitoring and management. Ann Univ Turk Ser. AII Tom University of Turku, Finland

Rönkä M, Saari L, Lehikoinen E, Suomela J, Häkkilä K (2005) Environmental changes and population trends of breeding waterfowl in northern Baltic Sea. Ann Zool Fenn 42:587-602

Rönkä M, Saari L, Hario M, Hänninen J, Lehikoinen E (2011) Breeding success and population trends of waterfowl - implications for monitoring. Wildlife Biol 17:225-239

Rönnbäck P, Kautsky N, Pihl L, Troell M, Söderqvist T, Wennhage H (2007) Ecosystem goods and services from Swedish coastal habitats: identification, valuation, and implications on ecosystem shifts. Ambio 36:534-544

Sanz JJ (2002) Climate change and breeding parameters of great and blue tits throughout the western Palaearctic. Global Change Biol 8:409-422

Schooley RL, Cotner LA, Ahlers AA, Heske EJ, Levengood JM (2012) Monitoring site occupancy for American Mink in its native range. J Wildlife Manage 76:824-831 
Schulze ED, Gash J, Freibauer A, Luyssaert S, Ciais P (eds) (2009) CarboEurope-IP, An Assessment of the European Terrestrial Carbon Balance. Jena

Schwartz M, Granö O, Pyökäri M (1989) Spits and tombolos in the southwest archipelago of Finland. J Coast Res 5:443-451

Seinä A, Peltola J (1991) Duration of the ice seasons and statistics of fast ice thickness along the Finnish coast 1961-1990. Finnish Marine Research 258

Şekercioğlu ÇH (2006) Increasing awareness of avian ecological function. Trends Ecol Evol 21:464-471

Şekercioğlu ÇH, Daily GC, Ehrlich PR (2004) Ecosystem consequences of bird declines. Proc Natl Acad Sci 101:18042-18047

Stock A, Tolvanen H, Kalliola R (2010) Crossing natural and dataset boundaries: Coastal terrain modelling in the southwest Finnish Archipelago. Int J Geogr Inform Sci 24:1435-1452

Störmer O (2011) Climate change impacts on coastal waters of the Baltic Sea. In: Schernewski G, Hofstede J, Neumann T (eds), Global Change and the Baltic Sea Coastal Zones. Springer, Dordrecht

Suominen T, Tolvanen H, Kalliola R (2010a) Geographical persistence of surface-layer water properties in the Archipelago Sea, SW Finland. Fennia 188:179-196

Suominen T, Tolvanen H, Kalliola R (2010b) Surface layer salinity gradients and flow patterns in the archipelago coast of SW Finland, northern Baltic Sea. Mar Environ Res 69:216-226

Sutherland WJ (ed) (2006) Ecological Census Techniques, a Handbook, 2nd edn. Cambridge University Press, Cambridge

Suutarinen O (1983) Recomputation of land uplift values in Finland. Rep Finn Geodetic Inst 83:1-16

Sweitzer J, Langaas S, Folke C (1996) Land cover and population density in the Baltic Sea drainage basin: A GIS database. Ambio 25:191-198

Tasker ML, Reid JB (1997) Seabirds in the marine environment. Introduction. ICES J Mar Sci 54:505-506

Thomas CD, Lennon JJ (1999) Birds extend their ranges northwards. Nature 399:213

Thuiller W, Lavorel S, Araújo MB, Sykes MT, Prentice IC (2005) Climate change threats to plant diversity in Europe. Proc Natl Acad Sci USA 102:8245-8250

Tiainen J (1985) Monitoring bird populations in Finland. Ornis Fennica 62:80-89

Tolvanen H, Kalliola R (2008) A structured approach to geographical information in coastal research and management. Ocean Coast Manag 51:485-494

Tolvanen H, Suominen T (2004) Classification of transitional archipelago environments based on shoreline dimensions. In: Proceedings of the Littoral 2004 Conference, 19-22 Sept 2004, Aberdeen p 136-137

Tolvanen H, Suominen T (2005) Quantification of openness and wave activity in archipelago environments. Estuar Coast Shelf Sci 64:436-446

Tolvanen H, Numminen S, Kalliola R (2004) Spatial distribution and dynamics of special shore-forms (tombolos, flads and glo-lakes) in an uplifting archipelago of the Baltic Sea. J Coast Res 20:234-243
Väisänen RA, Lammi E, Koskimies P (1998) Muuttuva pesimälinnusto. Otava, Helsinki

Valkama J, Vepsäläinen V, Lehikoinen A (2011) The Third Finnish Breeding Bird Atlas. Finnish Museum of Natural History and Ministry of Environment. http://atlas3.lintuatlas.fi/english (accessed 15 March 2012)

Vartiainen T (1988) Vegetation development on the outer island of the Bothnian Bay. Vegetatio 77:149-158

Vestøl O (2006) Determination of postglacial land uplift in Fennoscandia from leveling, tide-gauges and continuous GPS stations using least squares collocation. J Geod 80:248-258

Vihma T, Haapala J (2009) Geophysics of sea ice in the Baltic Sea: a review. Prog Oceanogr 80:129-148

Viitasalo M, Vuorinen I, Ranta E (1990) Changes in Crustacean mesozooplankton and some environmental parameters in the Archipelago Sea (northern Baltic) in 1976-1984. Ophelia 31: 207-217

Virkkala R, Rajasärkkä A (2011) Northward density shift of bird species in boreal protected areas due to climate change. Boreal Environ Res 16(SB):2-13

Virtaustutkimuksen neuvottelukunta (1979) Saaristomeren virtaustutkimus. Saaristomeren tutkimuslaitos, Nauvo

Voipio A, Leinonen M (1984) Itämeri. Kirjayhtymä, Helsinki

von Haartman L (1945) Zur biologie der wasser- und ufervögel im schärenmeer südwest-finnlands. Acta Zool Fenn 44:1-120

von Numers M (1995) Distribution, numbers and ecological gradients of birds breeding on small islands in the Archipelago Sea, SW Finland. Acta Zoolog Fennica 197

Wanless S, Harris MP, Redman P, Speakman JR (2005) Low energy values of fish as a probable cause of a major seabird breeding failure in the North Sea. Mar Ecol Prog Ser 294:1-8

Wasmund N, Tuimala J, Suikkanen S, Vandepitte L, Kraberg A (2011) Long-term changes in phytoplankton composition in the western and central Baltic Sea. J Mar Syst 87:145-159

Westerbom M, Mustonen O, Kilpi M (2008) Distribution of a marginal population of Mytilus edulis: responses to biotic and abiotic processes at different spatial scales. Mar Biol 153:1153-1164

Wolf A, Callaghan TV, Larson K (2007) Future changes in vegetation and ecosystem function of the Barents Region. Climatic Change 87:51-73

Zaehle S, Bondeau A, Carter TR, Cramer W, Erhard M, Prentice IC, Reginster I, Rounsevell MD Sitch S, Smith B, Smith PC, Sykes M (2007) Projected changes in terrestrial carbon storage in Europe under climate and land-use change, 1990-2100. Ecosystems $10: 380-401$

Zaiko A, Lehtiniemi M, Narscius A, Olenin S (2011) Assessment of bioinvasion impacts on a regional scale: a comparative approach. Biol Invasions 13:1739-1765

Zolina O, Simmer C, Gulev S, Kollet S (2010) Changing structure of European precipitation: longer wet periods leading to more abundant rainfalls. Geophys Res Lett 37: L06704. doi:10.1029/ 2010GL042468 